\title{
Signalling and anti-proliferative effects mediated by gonadotrophin-releasing hormone receptors after expression in prostate cancer cells using recombinant adenovirus
}

\author{
J Franklin, J Hislop, A Flynn and C A McArdle \\ University Research Centre for Neuroendocrinology, University of Bristol, Bristol BS2 8HW, UK \\ (Requests for offprints should be addressed to C A McArdle; Email: craig.mcardle@bris.ac.uk)
}

\begin{abstract}
Gonadotrophin-releasing hormone receptors (GnRH-Rs) are found in cancers of reproductive tissues, including those of the prostate, and gonadotrophin-releasing hormone $(\mathrm{GnRH})$ can inhibit growth of cell lines derived from such cancers. Although pituitary and extra-pituitary GnRH-R transcripts appear identical, their functional characteristics may differ. Most extra-pituitary GnRH-Rs have low affinity for $\mathrm{GnRH}$ analogues and may not activate phospholipase $\mathrm{C}$ or discriminate between agonists and antagonists in the same way as do pituitary GnRHRs. Here we have assessed whether GnRH-Rs expressed exogenously in prostate cancer cells differ functionally from those of gonadotrophs. We found no evidence for endogenous GnRH-Rs in PC3 cells, but after infection with adenovirus expressing the GnRH-R (Ad GnRH-R) at 10 plaque forming units (p.f.u.)/cell or greater, at least $80 \%$ of the cells expressed GnRH-Rs. These sites had high affinity $\left(K_{\mathrm{d}}\right.$ for $\left[{ }^{125} \mathrm{I}\right]$ Buserelin $\left.1 \cdot 1 \pm 0 \cdot 4 \mathrm{nM}\right)$ and specificity (rank order of potency: Buserelin> GnRH >>chicken (c) GnRH-II), and mediated stimulation of $\left[{ }^{3} \mathrm{H}\right]$ inositol phosphate (IP) accumulation. Increasing viral titre from 3 to 300 p.f.u./cell increased
\end{abstract}

receptor number (2000 to 275000 sites/cell respectively) and $\left[{ }^{3} \mathrm{H}\right] \mathrm{IP}$ responses. GnRH also caused a biphasic increase in the cytoplasmic $\mathrm{Ca}^{2+}$ concentration in $\mathrm{Ad}$ GnRH-R-infected cells but not in control cells. Mobilization of $\mathrm{Ca}^{2+}$ from intracellular stores contributed to the spike phase of this response whereas the plateau phase was dependent upon $\mathrm{Ca}^{2+}$ entry across the plasma membrane. This effect on $\mathrm{Ca}^{2+}$ and stimulation of $\left[{ }^{3} \mathrm{H}\right] \mathrm{IP}$ accumulation were both blocked by the GnRH-R antagonist, Cetrorelix. In addition, GnRH reduced cell number (as measured in MTT activity assays) and DNA synthesis (as measured by $\left[{ }^{3} \mathrm{H}\right]$ thymidine incorporation) in $\mathrm{Ad}$ GnRH-R-infected cells (but not in control cells). This effect was mimicked by agonist analogues and inhibited by two antagonists. Thus, when exogenous GnRH-Rs are expressed at a density comparable to that in gonadotrophs, they are functionally indistinguishable from the endogenous GnRH-Rs in gonadotrophs. Moreover, expression of high affinity GnRH-Rs can facilitate a direct antiproliferative effect of $\mathrm{GnRH}$ agonists on prostate cancer cells.

Journal of Endocrinology (2003) 176, 275-284

\section{Introduction}

Gonadotrophin-releasing hormone $(\mathrm{GnRH})$ is the key hormone in the regulation of reproduction and is responsible for stimulating the secretion of follicle-stimulating hormone and luteinizing hormone (Conn \& Crowley 1994). At the pituitary, GnRH acts via G-protein coupled receptors (GPCRs) which cause a $\mathrm{G}_{\mathrm{q} / 11}$-mediated activation of phospholipase $\mathrm{C}$ (PLC) and a consequent inositol trisphosphate $\left(\mathrm{IP}_{3}\right)$-mediated mobilization of $\mathrm{Ca}^{2+}$ from intracellular stores (Sealfon et al. 1997). GnRH-stimulated gonadotrophin secretion can be blocked with antagonists, or mimicked by agonists, but in the latter case, sustained stimulation causes desensitization. Thus, both agonists and antagonists ultimately reduce circulating gonadotrophins and gonadal steroids. This 'medical castration' is exploited to treat sex hormone dependent neoplasms such as those of the prostate, ovary, endometrium or breast (Barbieri 1992, Conn \& Crowley 1994). However, GnRH receptors (GnRH-Rs) (often along with GnRH) may also be expressed in these cancers (Miller et al. 1985, Emons \& Schally 1994, Emons et al. 1996, 1997, Moretti et al. 1996, Motta et al. 1996, Schally 1999, Gruendker \& Emons 2001, Schally et al. 2001). Interest in these receptors stems primarily from the fact that $\mathrm{GnRH}$ analogues (or cytotoxic derivatives thereof) can inhibit proliferation of cell lines derived from such cancers, implying that such direct effects may contribute to the efficacy of GnRH analogues in cancer therapy (Miller et al. 1985, Qayum et al. 1990, Limonta et al. 1992, Dondi et al. 1994, Emons \& Schally 
1994, Emons et al. 1997, Jungwirth et al. 1997, Bahk et al. 1998, Palyi et al. 1999, Schally 1999, Halmos et al. 2000, Ravenna et al. 2000, Schally et al. 2001).

Investigation of the extra-pituitary GnRH-Rs has revealed major functional differences between GnRH-Rs in pituitary and extra-pituitary sites, in spite of the expression of identical receptor transcripts (Kakar et al. 1994). In radioligand binding studies (Emons et al. 1997), pituitary GnRH-Rs have high affinity for agonists such as Buserelin (nM $K_{\mathrm{d}}$ values) whereas most extra-pituitary expressed GnRH-Rs have low affinity ( $\mu \mathrm{M} K_{\mathrm{d}}$ values). In the pituitary, GnRH-Rs are coupled via $\mathrm{G}_{\mathrm{q} / 11}$ to PLC, causing an $\mathrm{IP}_{3}$-mediated mobilization of $\mathrm{Ca}^{2+}$ and a protein kinase $\mathrm{C}$-mediated activation of MAP kinases, but there is little evidence for PLC activation by endogenous extra-pituitary GnRH-Rs (Emons et al. 1997, Limonta et al. 2001). Instead, $G_{\mathrm{i}}$-mediated activation of protein phosphatase and inhibition of MAP kinase activity may underlie at least some of the antiproliferative effects mediated by GnRH-Rs (Moretti et al. 1996, Imai et al. 1997, Emons et al. 1998, Gruendker et al. 2001, Limonta et al. 2001). A further intriguing distinction is that peptides which act as competitive antagonists of pituitary GnRH-Rs have been shown to mimic effects of agonists in cancer cells (including those of the prostate), implying that the agonist/antagonist dichotomy established for pituitary GnRH-Rs may not be applicable to extra-pituitary GnRH-Rs (Emons et al. 1997, Limonta et al. 1997, 2001). In some cancers, however, locally produced $\mathrm{GnRH}$ may actually support (rather than inhibit) proliferation, such that agonists and antagonists can reduce proliferation by down-regulation and blockade (respectively) of GnRH-Rs (Arencibia \& Schally 2000).

The stoichiometry of receptors to effectors and accessory proteins can influence receptor function and, since this can vary from cell-to-cell and with receptor number, operational characteristics of GPCRs can vary according to receptor density and cellular context. Accordingly, the reported differences between pituitary and extra-pituitary receptors could reflect an extreme degree of contextdependent signalling by this receptor. To test this possibility we have recently developed recombinant adenovirus expressing GnRH-Rs and have begun to use these to express GnRH-Rs, at a density which would be physiological for pituitary GnRH-Rs, in a human cancerderived cell line reported to express endogenous GnRH-Rs (Everest et al. 2001). Here we show that recombinant adenovirus provides a simple means of expressing functional GnRH-Rs in an androgenindependent human prostate cancer cell line (PC3), that the operational characteristics of these receptors are similar to those of pituitary GnRH-Rs, and that expression of these receptors facilitates a pronounced anti-proliferative effect of GnRH-Rs agonists (but not antagonists). Accordingly, although we have found no evidence for contextdependence of GnRH-R signalling, we have shown that
GnRH-R numbers are limiting for its direct antiproliferative effect, implying that manipulations that increase or maintain GnRH-R numbers in prostate cancer may increase the effectiveness of direct GnRH-R targeted therapy.

\section{Materials and Methods}

\section{Materials}

Peptides were purchased from Peninsula Laboratories Europe Ltd (Merseyside, UK) or from Sigma (Poole, Dorset, UK) with the exception of Buserelin and $\left[{ }^{125} \mathrm{I}\right]$ Buserelin $(2000 \mathrm{Ci} / \mathrm{mmol})$ which were donated by Professor J Sandow (Aventis Pharma GmbH, Frankfurt, Germany) and Cetrorelix which was donated by Asta Medica (Frankfurt am Main, Germany). Culture media were from Sigma, sera were from First Link (Brierly Hill, Staffs, UK) and plasticware was from Gibco BRL (Paisley, UK) or Falcon (Becton Dickinson, Oxford, UK). All other reagents were purchased from standard commercial suppliers.

\section{Cell culture and transfection}

PC3 cells (European Collection of Cell Cultures and Cell Lines, Salisbury, UK) were cultured in RPMI with 10\% calf serum, $50 \mathrm{iu} / \mathrm{ml}$ penicillin, $50 \mu \mathrm{g} / \mathrm{ml}$ streptomycin and $2 \mathrm{mM}$ L-glutamine. They were maintained at $37^{\circ} \mathrm{C}$ in humidified air/ $\mathrm{CO}_{2}$ (19:1) and passaged weekly. For experiments, cells were harvested by trypsinization, then incubated for 1-7 days in culture plates as described. Cells were transfected by infection with recombinant replication-deficient adenovirus expressing sheep GnRH-Rs (Ad GnRH-R), prepared as described (Hislop et al. 2000, Everest et al. 2001). Viral titre was determined in a standard plaque formation assay and is expressed as the number of plaque forming units per plated PC3 cell (p.f.u./cell). In some experiments a control empty adenovirus was used (identical to Ad GnRH-R except that it lacks the GnRH-R sequence). Adenovirus was typically added to the cultured PC3 cells $24 \mathrm{~h}$ after plating.

\section{Radioligand binding assays}

A whole-cell suspension binding assay was used to determine number and pharmacological characteristics of expressed GnRH-Rs (Hislop et al. 2000, Everest et al. 2001). Twenty-four hours after plating at 200000 cells/well in 6-well plates, PC3 cells were infected with Ad GnRH at 0-300 p.f.u./cell. They were then incubated for a further 24 to $48 \mathrm{~h}$ at $37^{\circ} \mathrm{C}$ before being scraped from the plate, pelleted and resuspended in a physiological salt solution (PSS; $127 \mathrm{mM} \mathrm{NaCl}, 1.8 \mathrm{mM} \mathrm{CaCl}_{2}, 5 \mathrm{mM} \mathrm{KCl}, 2 \mathrm{mM}$ $\mathrm{MgCl}, 0.5 \mathrm{mM} \mathrm{NaH} \mathrm{PO}_{4}, 5 \mathrm{mM} \mathrm{NaHCO}, 10 \mathrm{mM}$ 
glucose, $0 \cdot 1 \% \mathrm{BSA}$ and $10 \mathrm{mM}$ Hepes (pH 7.4)) which contained $1 \mathrm{mg} / \mathrm{ml}$ bacitracin. The number and affinity of GnRH-Rs expressed were determined by competition radioligand binding using $\left[{ }^{125} \mathrm{I}\right]$ Buserelin (approximately $10^{-10} \mathrm{M}$ ) and $10^{-12}-10^{-6} \mathrm{M}$ unlabelled Buserelin. After $30 \mathrm{~min}$ at room temperature $\left(21^{\circ} \mathrm{C}\right)$, free and bound ligand were separated by centrifugation through oil as described (Hislop et al. 2000, Everest et al. 2001). The binding data were analysed by non-linear least square curve fitting using Prism software (GraphPad Software Inc., San Diego, CA, USA) to calculate $K_{\mathrm{d}}$ and $\mathrm{B}_{\max }$. Cell number was determined in parallel enabling calculation of receptor number per cell. Ligand specificity was assessed in a similar manner, except that the unlabelled competing peptide was varied. Some binding experiments were also performed using adherent cells in 96-well plates. These were seeded at 10000 cells/well, infected 24 h later with Ad GnRH-R (100 p.f.u./cell) and then maintained for a further $24 \mathrm{~h}$. The cells were then washed several times with PSS and incubated in PSS with $1 \mathrm{mg} / \mathrm{ml}$ bacitracin with varying concentrations of unlabelled competitor peptide and approximately $10^{-10} \mathrm{M}\left[{ }^{125} \mathrm{I}\right]$ Buserelin for $30 \mathrm{~min}$ at room temperature $\left(21^{\circ} \mathrm{C}\right)$. The cells were washed four times with ice cold PSS and then solubilized in $0 \cdot 2 \mathrm{M} \mathrm{NaOH} / 10 \%$ SDS. Radioactivity was determined using a gamma counter.

\section{$\left.\Gamma^{3} H\right]$ Inositol phosphate ( $\left.\left.\Gamma^{3} H\right] I P\right)$ accumulation}

Phospholipase C activity was quantified as $\left[{ }^{3} \mathrm{H}\right] \mathrm{IP}$ accumulation in cells labelled with $\left[{ }^{3} \mathrm{H}\right]$ inositol and stimulated in the presence of LiCl (McArdle et al. 1992a, Everest et al. 2001). Cells were seeded at 50000 cells/well into 24-well plates and infected $24 \mathrm{~h}$ later with Ad GnRH-R (0 or 100 p.f.u./cell). After a further $24 \mathrm{~h}, 2 \mathrm{mCi}\left[2-{ }^{3} \mathrm{H}\right]$ inositol $(14-16 \mathrm{Ci} / \mathrm{mmol})$ were added. The cells were then incubated overnight (approximately $16 \mathrm{~h}$ ) before being washed (twice) in PSS and stimulated for $30 \mathrm{~min}$ with $250 \mu \mathrm{l}$ PSS containing $10^{-2} \mathrm{M} \mathrm{LiCl}$ and the indicated concentrations of agonist. Stimulation was terminated with $1 \mathrm{ml}$ water at $95^{\circ} \mathrm{C}$. After freezing and thawing, separation of $\left[{ }^{3} \mathrm{H}\right]$ inositol phosphates and free $\left[{ }^{3} \mathrm{H}\right]$ inositol was achieved by anion exchange chromatography, as described (Everest et al. 2001).

\section{Dynamic video imaging of cytoplasmic $\mathrm{Ca}^{2+}$}

The cytoplasmic $\mathrm{Ca}^{2+}$ concentration was measured by video imaging in fura 2-loaded PC3 cells as described (McArdle et al. 1992b, Everest et al. 2001). Briefly, cells were seeded onto glass cover-slips at $50000 \mathrm{cells} / \mathrm{ml}$ and infected with Ad GnRH-R 24 h later. After incubation for a further $24 \mathrm{~h}$, they were washed in PSS and then exposed to $2 \mu \mathrm{M}$ fura-2/AM (in PSS) for $30 \mathrm{~min}$ at $37^{\circ} \mathrm{C}$. The cover-slips were then washed and loaded into a stainless steel holder fitted into a heating chamber at $37^{\circ} \mathrm{C}$. Image capture was performed within 5-25 min of loading in approximately $500 \mu \mathrm{l}$ PSS or in a modified PSS containing $100 \mu \mathrm{M}$ EGTA and no $\mathrm{CaCl}_{2}\left(\mathrm{Ca}^{2+}\right.$-free medium), and calibration was as described (Everest et al. 2001).

\section{MTT (3-(4,5-dimethylthiazol-2-yl)2,5-diphenyl-tetrazolium bromide) reduction}

MTT reduction was used as a measure of viable cell number (Everest et al. 2001). The cells were routinely seeded at 2500 cells/well into 96-well plates. After $24 \mathrm{~h}$ they were transferred to medium with $1 \%$ FCS and the Ad GnRH-R was added at this time. After $24 \mathrm{~h}$ the cells were stimulated with the indicated peptide and 3 days later $50 \mu \mathrm{l}$ MTT solution $(5 \mathrm{mg} / \mathrm{ml}$ in water) were added to the culture medium. After $4 \mathrm{~h}$ at $37{ }^{\circ} \mathrm{C}$ the medium was removed and $50 \mu \mathrm{l}$ acidified isopropanol $\left(10^{-2} \mathrm{M} \mathrm{HCl}\right.$ in isopropanol) were added to each well. The colour was allowed to develop for $5 \mathrm{~min}$ and optical density at $550 \mathrm{~nm}$ was determined. In some experiments cell number and incubation times were varied as described in the Figure legends.

\section{$\left.P^{3} H\right]$ Thymidine incorporation}

Incorporation of $\left[{ }^{3} \mathrm{H}\right]$ thymidine into newly synthesized DNA was used as a measure of cell proliferation (Williams et al. 2000, Everest et al. 2001). Cells were seeded into 96-well plates at 2500 cells/well and $24 \mathrm{~h}$ later the media were replaced with medium containing $1 \%$ FCS and the required amount of Ad GnRH-R. Twenty-four hours later the cells were stimulated with the indicated peptides and 3 days later $10 \mu \mathrm{l}\left[{ }^{3} \mathrm{H}\right]$ thymidine were added to each well. After a further $4 \mathrm{~h}$ at $37^{\circ} \mathrm{C}$, the media were removed and $100 \mu \mathrm{l}$ trypsin/EDTA were added to each well. The cells were incubated at $37^{\circ} \mathrm{C}$ for $30 \mathrm{~min}$ after which the plates were stored at $-20{ }^{\circ} \mathrm{C}$. Incorporated $\left[{ }^{3} \mathrm{H}\right]$ thymidine was collected and measured as described (Everest et al. 2001).

\section{Results}

In preliminary experiments, transfection efficiency was assessed using a range of conventional (lipid or calcium phosphate based) techniques and flow cytometry to quantify expression of green-fluorescent protein (GFP) after transfection with a GFP vector. Using conventional techniques $<20 \%$ of PC3 cells were transfected whereas $>80 \%$ of the cells were transfected after infection with a recombinant adenovirus expressing GFP at $>10$ p.f.u./cell. These data (not shown) were very similar to those obtained in other cancer cell lines (see Hislop et al. 2000 and Everest et al. 2001 for details of methods) and recombinant adenovirus expressing GnRH-Rs were 


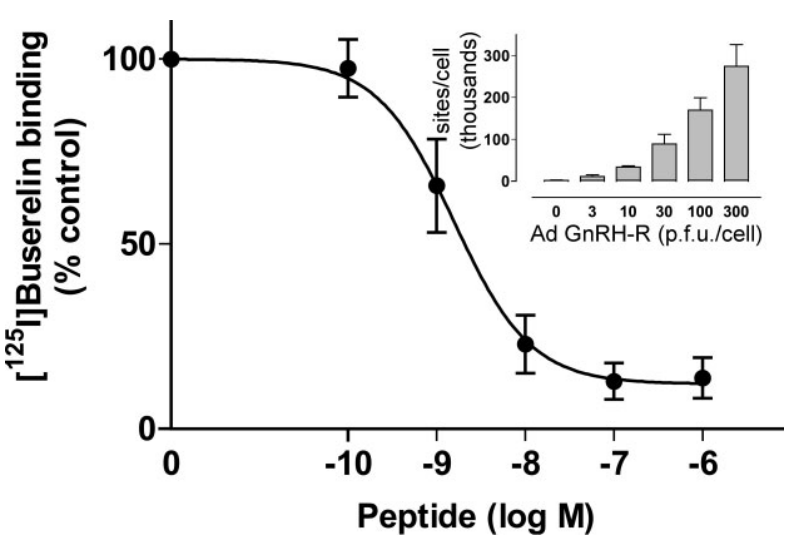

Figure $1 \mathrm{GnRH}-\mathrm{R}$ expression in Ad GnRH-R-infected PC3 cells: binding affinity and receptor number. Main panel: PC3 cells were infected with Ad GnRH-R at 100 p.f.u./cell, then cultured for $48 \mathrm{~h}$ before use in suspension binding assays. Data shown are means \pm S.E.M. and are pooled from seven experiments $(n=3-7)$, each with duplicate or triplicate observations and normalized as a percentage of the internal control binding (without competitor). Inset: PC3 cells were infected with Ad GnRH-R at the indicated titre then cultured for $48 \mathrm{~h}$ and used in suspension binding experiments with $\left[{ }^{125} \mathrm{I}\right]$ Buserelin and 0 or $10^{-6} \mathrm{M}$ unlabelled Buserelin (non specific binding). The figure shows receptor number per cell, calculated as described in the Results. Data are from three independent experiments, each having triplicate observations $(n=3)$.

therefore used for the remainder of this study. Whole cell radioligand binding studies with $\left[{ }^{125} \mathrm{I}\right]$ Buserelin revealed no endogenous specific sites in control cells but after infection with Ad GnRH-R (100 p.f.u./cell) specific binding sites were clearly present (Fig. 1, main panel). Competition analysis revealed the presence of a single high affinity site with a $K_{\mathrm{d}}$ value of $1 \cdot 1 \pm 0 \cdot 4 \mathrm{nM}$ (Fig. 1). In a second series of experiments, cells were infected with $\mathrm{Ad}$ GnRH-R at various titres prior to single point binding assays. As adenoviral titres were increased from 3 to 300 p.f.u. $/ \mathrm{ml}$, specific $\left.{ }^{125} \mathrm{I}\right]$ Buserelin increased from approximately 2000 to 275000 sites/cell. The number of receptors per cell was calculated from the specific binding and cell counts (performed in parallel) assuming a $K_{\mathrm{d}}$ of $1 \cdot 1 \mathrm{nM}$ and a Hill coefficient of 1 (in which case the tracer used occupies approximately $10 \%$ of the receptors at equilibrium). This calculation most likely causes a modest underestimate of receptor number at low adenoviral titre because it assumes 100\% transfection efficiency. At 10 p.f.u./cell, for example, transfection efficiency is approximately $80 \%$ (estimated as described above) so receptor number (in the subset of cells that are transfected) is underestimated by approximately $25 \%$. At higher titres transfection efficiency increases to $>90 \%$ so that this error is reduced.

In order to assess ligand specificity, competition curves were constructed using $\left[{ }^{125} \mathrm{I}\right]$ Buserelin and various concentrations of Buserelin, GnRH and chicken (c) GnRH-II
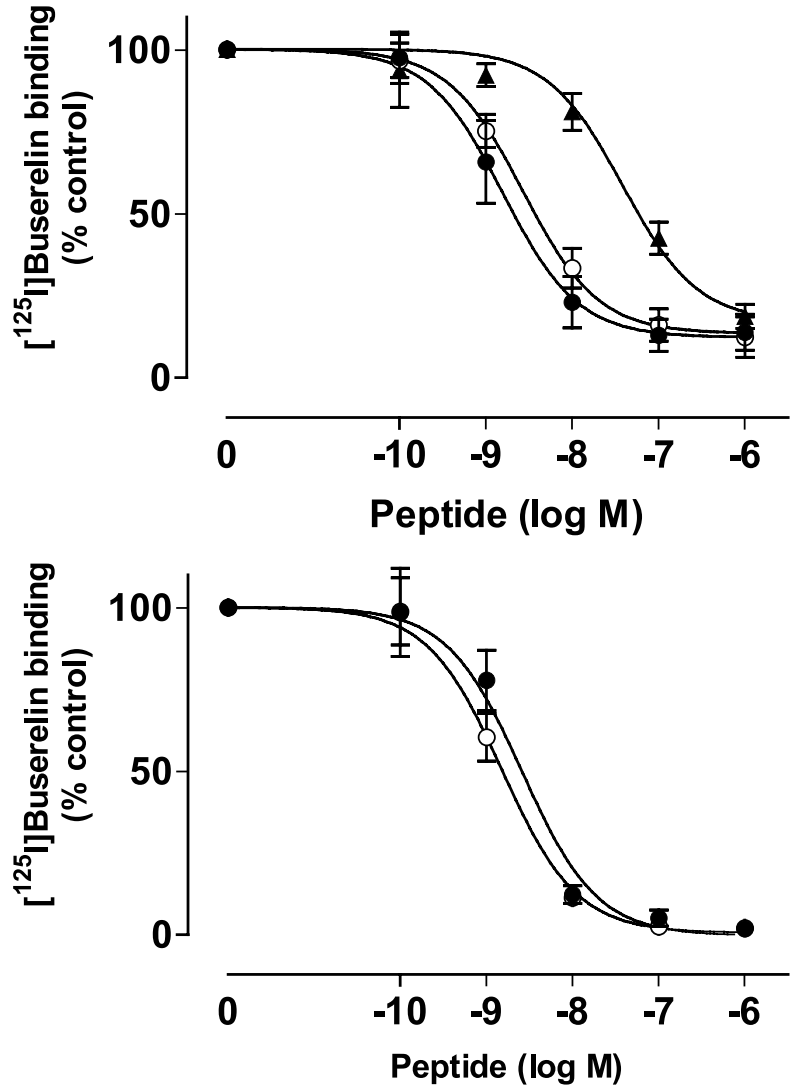

Figure 2 GnRH-R expression in Ad GnRH-R-infected PC3 cells: binding specificity. PC3 cells were infected with Ad GnRH-R at 100 p.f.u./cell, then cultured for $48 \mathrm{~h}$ before use in a suspension binding assay using $\left[{ }^{125} \mathrm{I}\right]$ Buserelin and the indicated concentrations of agonists (upper panel: Buserelin (solid circles), GnRH (open circles), cGnRH-II (solid triangles)) or antagonists (lower panel: Antide (open circles), Cetrorelix (solid circles)). Data shown are means \pm S.E.M. from seven experiments, each having duplicate or triplicate observations $(n=3-7)$ and are normalized as a percentage of the internal control (without competitor).

(agonists at pituitary GnRH-Rs) as well as Cetrorelix and Antide (antagonists at pituitary GnRH-Rs). As shown, all five peptides competed with $\left[{ }^{125} \mathrm{I}\right]$ Buserelin for binding (Fig. 2). The rank order of potency for the agonists (Buserelin $>\mathrm{GnRH}>>\mathrm{cGnRH}-\mathrm{II}$ ) was similar to that seen with endogenous pituitary GnRH-Rs and with type I GnRH-Rs expressed in other heterologous systems (Sealfon et al. 1997, Hislop et al. 2000, Everest et al. 2001). To determine whether these binding sites are functional receptors, effects on $\left[{ }^{3} \mathrm{H}\right] \mathrm{IP}$ accumulation and $\mathrm{Ca}^{2+}$ mobilization were assessed. In control cells, GnRH failed to increase $\left[{ }^{3} \mathrm{H}\right] \mathrm{IP}$ accumulation or cytosolic $\mathrm{Ca}^{2+}$ ion concentration $\left(\left[\mathrm{Ca}^{2+}\right]_{\mathrm{i}}\right)$. However, after infection with Ad GnRH-R (100 p.f.u./cell) GnRH caused a clear and dose-dependent increase in $\left[{ }^{3} \mathrm{H}\right] \mathrm{IP}$ accumulation (Fig. 3) with an $\mathrm{EC}_{50}$ value of $0.86 \pm 0.42 \mathrm{nM}$. Buserelin and cGnRH-II caused similar dose-dependent effects with 


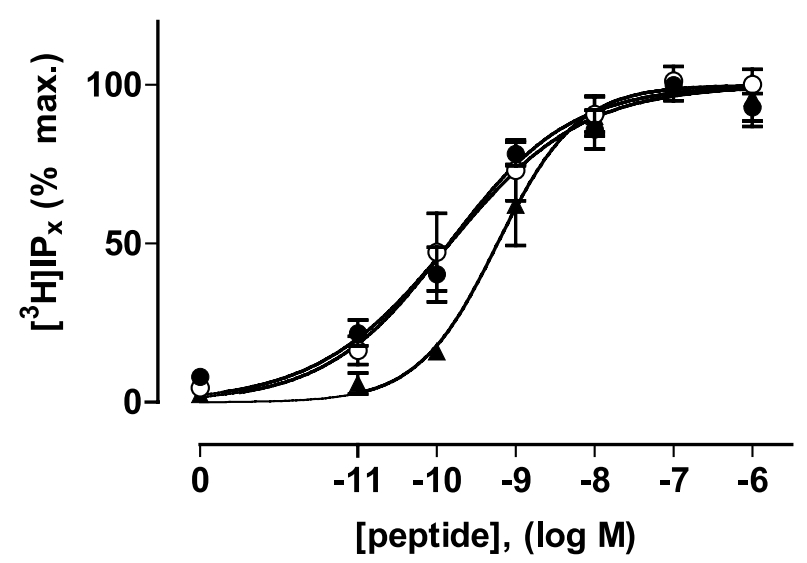

Figure 3 GnRH-R expression in Ad GnRH-R-infected PC3 cells: $\left[{ }^{3} \mathrm{H}\right] \mathrm{IP}$ accumulation. $\left[{ }^{3} \mathrm{H}\right] \mathrm{IP}$ accumulation was measured in $\left[{ }^{3} \mathrm{H}\right]$ inositol-labelled cells, stimulated for $30 \mathrm{~min}$ with the indicated concentration of Buserelin (open circles), GnRH (solid circles) or cGnRH-II (triangles), in PSS with $10^{-2} \mathrm{M} \mathrm{LiCl}$. The data shown are means \pm S.E.M. from five experiments, each having been performed in triplicate. The $\left[{ }^{3} \mathrm{H}\right] \mathrm{IP}$ responses were normalized as a percentage of the internal control maximum response to each peptide.

$\mathrm{EC}_{50}$ values of $0.23 \pm 0.04 \mathrm{nM}$ and $2.96 \pm 1.35 \mathrm{nM}$ respectively, and stimulation of $\left[{ }^{3} \mathrm{H}\right] \mathrm{IP}$ accumulation by $10^{-9} \mathrm{M}$ GnRH was abolished by $10^{-7} \mathrm{M}$ Antide or Cetrorelix (not shown). In cells infected with Ad GnRH-R (100 p.f.u./cell) $10^{-8} \mathrm{M}$ GnRH also caused a robust increase in $\left[\mathrm{Ca}^{2+}\right]_{\mathrm{i}}$ (Fig. 4) whereas no such increase was seen in control (uninfected) cells. In individual cells GnRH typically caused a spike-plateau type increase or a gradual increase to a sustained plateau and the magnitude of this response varied greatly from cell to cell, with some cells $(<40 \%)$ showing no increase and others showing increases to over $10^{-6} \mathrm{M}$ (not shown). Although GnRH causes oscillatory $\mathrm{Ca}^{2+}$ responses in other systems, a clear oscillatory increase in $\left[\mathrm{Ca}^{2+}\right]_{i}$ was seen in only one cell (e.g. $<0.5 \%$ of the imaged population, not shown). When the cells were transferred to $\mathrm{Ca}^{2+}$-free medium (containing $10^{-7} \mathrm{M} \mathrm{GnRH}$ ) during the plateau phase of the response, the $\left[\mathrm{Ca}^{2+}\right]_{\mathrm{i}}$ was rapidly decreased (Fig. 4). When the cells were transferred to $\mathrm{Ca}^{2+}$-free medium prior to stimulation with $\mathrm{GnRH}$, the peptide caused only a modest and transient increase in $\left[\mathrm{Ca}^{2+}\right]_{\mathrm{i}}$, subsequent transfer to normal medium (still containing $\mathrm{GnRH}$ ) elicited an increase in $\left[\mathrm{Ca}^{2+}\right]_{\mathrm{i}}$ to the plateau level (Fig. 4). Thus, in Ad GnRH-R-infected PC3 cells GnRH causes an initial spike-phase increase in $\left[\mathrm{Ca}^{2+}\right]_{i}$ which is (at least in part) dependent upon mobilization from intracellular stores, followed by a plateau increase which is dependent upon $\mathrm{Ca}^{2+}$ entry across the plasma membrane. These data are characteristic of responses seen on robust activation of PLC-coupled GPCRs and are qualitatively similar to those seen in pituitary cells with endogenous or exogenous GnRH-Rs (Hislop et al. 2000, Stojilkovic \& Catt 1995).
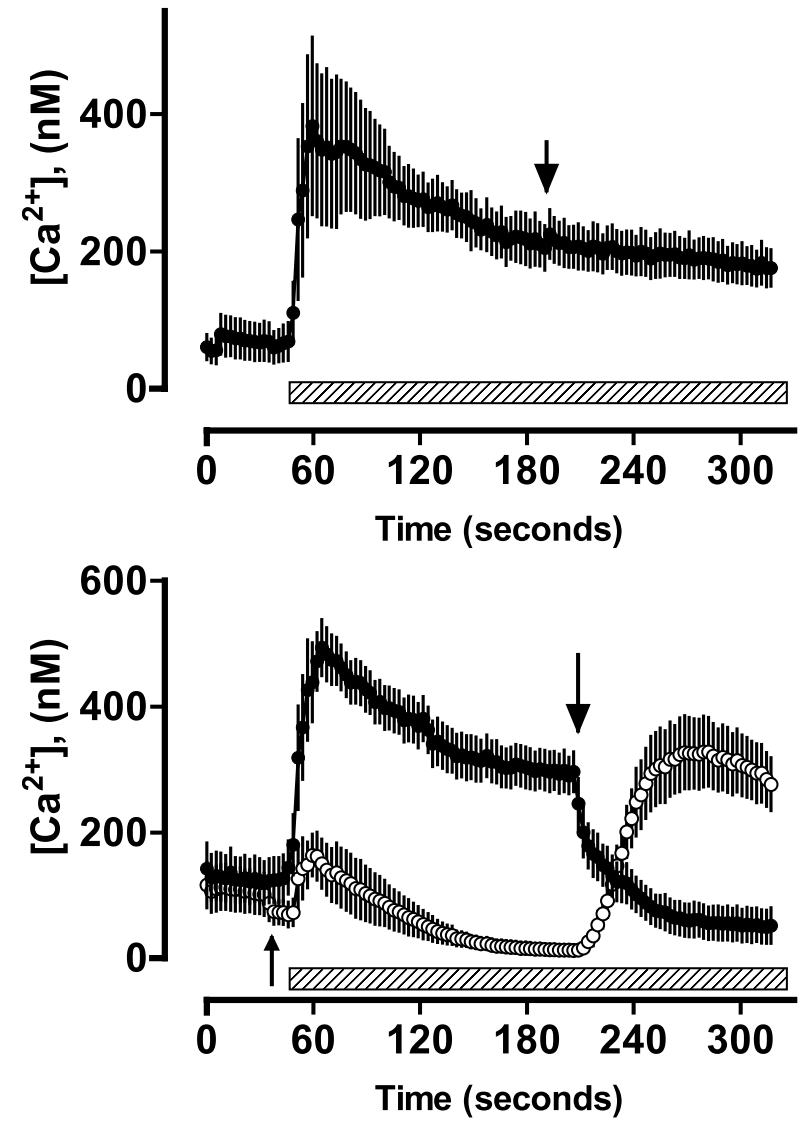

Figure 4 Effect of $\mathrm{GnRH}$ on $\left[\mathrm{Ca}^{2+}\right]_{\mathrm{i}}$ in Ad GnRH-R-infected PC3 cells. PC3 cells were infected with Ad GnRH-R at 100 p.f.u./cell, and then cultured for one day before being loaded with fura 2 and used for $\mathrm{Ca}^{2+}$ imaging. Upper panel: cells infected with $\mathrm{Ad}$ GnRH-R were stimulated with $10^{-7} \mathrm{M} \mathrm{GnRH}$ (horizontal bar). The arrow indicates a change of control medium (e.g. GnRH to $\mathrm{GnRH})$. Lower panel: cells were stimulated with $10^{-7} \mathrm{M} \mathrm{GnRH}$ in normal medium and this was then replaced (indicated by the large vertical arrow) with $\mathrm{Ca}^{2+}$-free medium containing $10^{-7} \mathrm{M} \mathrm{GnRH}$ (solid circles). Alternatively, the cells were transferred to $\mathrm{Ca}^{2+}$-free medium (small vertical arrow) before stimulation with $\mathrm{GnRH}$ (horizontal bar) first in $\mathrm{Ca}^{2+}$-free medium and then (indicated by the large vertical arrow) in $\mathrm{Ca}^{2+}$-containing medium (open circles). The traces are the means \pm S.E.M. from the pooled data of $8-10$ experiments with responses of 10-50 cells averaged for each experiment. In control uninfected cells, GnRH failed to alter the $\left[\mathrm{Ca}^{2+}\right]_{\mathrm{i}}$ (not shown).

Since it has previously been shown that GnRH analogues can directly inhibit the proliferation of PC3 cells, we assessed whether infection with Ad GnRH-R was able to enhance or facilitate any such effect. We found no effect of GnRH or Buserelin (both at $10^{-7} \mathrm{M}$ ) on MTT reduction in control uninfected PC3 cells or in PC3 cells infected with an empty adenovirus at 100 p.f.u./cell (Fig. 5) but after infection with Ad GnRH-R, GnRH and Buserelin both reduced MTT activity by $40-60 \%$. In subsequent experiments viral titre and duration of 


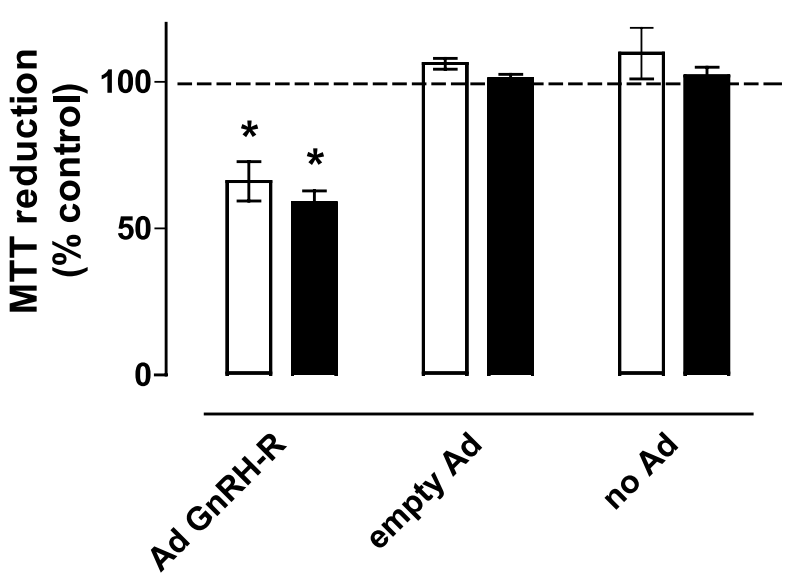

Figure 5 Effect of Buserelin on MTT activity in PC3 cells: dependence on Ad GnRH-R infection. Cells were infected with empty adenovirus (empty Ad; 100 p.f.u./cell), with Ad GnRH-R (100 p.f.u./cell) or were uninfected (no Ad), then cultured with $10^{-7} \mathrm{M}$ of either GnRH (open bars) or Buserelin (solid bars) (control cells received no peptide) and MTT activity was determined on the last day of culture. The data are from five separate experiments (means \pm S.E.M., $n=5$ ) each with four replicate observations. For pooling, the data were normalized as a percentage of the MTT activity seen in control cells receiving no peptide and the control values did not differ significantly from each other. ${ }^{*} P<0.05$ compared with internal control value of $100 \%$ (dotted line).

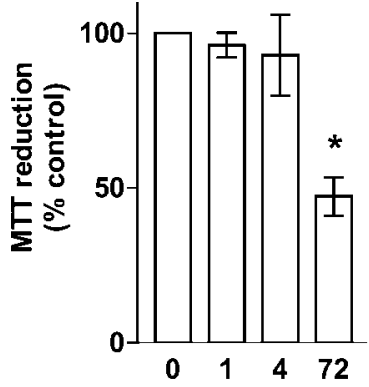

Time (hours)

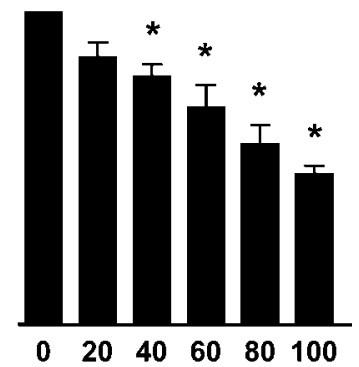

Titre (p.f.u./cell)
Figure 6 GnRH-R-mediated effects on MTT activity in PC3 cells: dependence on time and Ad GnRH-R titre. Left panel (open bars): cells were infected with Ad GnRH-R (100 p.f.u./cell) and this was removed by aspiration and washing immediately $(\mathrm{t}=0)$ or after 1 , 4 or $72 \mathrm{~h}$, as indicated. Approximately $24 \mathrm{~h}$ later, 0 or $10^{-10} \mathrm{M}$ Buserelin were added and the cells were cultured for $72 \mathrm{~h}$ prior to measurement of MTT activity. Right panel (solid bars): cells were cultured, Ad infected and stimulated with 0 or $10^{-10} \mathrm{M}$ Buserelin, as described above (sustained exposure to Buserelin) except that the Ad titre was varied from 0 to 100 p.f.u./cell, as indicated. The data are from four separate experiments (means \pm S.E.M., $n=3-4$ ) each of which had four replicate observations. For pooling, the data were normalised as a percentage of the MTT activity seen in control cells receiving no peptide. ${ }^{*} P<0.05$ compared with internal control value of $100 \%$.

exposure to Buserelin were varied. As shown in Fig. 6, treatment of Ad GnRH-R-infected cells for 1 or $4 \mathrm{~h}$ with $10^{-10} \mathrm{M}$ Buserelin had little effect on MTT activity, whereas continuous exposure to Buserelin for 3 days reduced MTT activity by approximately $50 \%$. Moreover, the inhibitory effect of 3-day treatments with $10^{-10} \mathrm{M}$ Buserelin increased as viral titre was increased from 20 to 100 p.f.u./cell. This reflects dependence on receptor number (rather than on percentage of cells transfected) because we have estimated that at least $80 \%$ of cells are transfected under these conditions (above). In related experiments (not shown), the inhibitory effect of Buserelin was found to be essentially independent both of cell number at plating (between 1500 and 4500 cells/well) and of period of stimulation (between 1 and 6 days). Accordingly, all subsequent experiments were performed using 3 days of continuous exposure to test peptides after seeding at 2500 cells/well and infection at 100 p.f.u./ plated cell.

In order to explore ligand specificity, the effects of Buserelin, GnRH and Cetrorelix (antagonist at pituitary GnRH-Rs) on MTT activity were determined. As demonstrated in Fig. 7 (upper panel), each of the agonists produced a dose-dependent reduction in cell viability, with Buserelin being more potent and effective than GnRH. Chicken GnRH-II also reduced MTT activity and its effect was comparable to that of GnRH (not shown). In contrast, Cetrorelix did not measurably influence MTT activity and similar data were obtained with Antide (not shown). Similar experiments were performed using $\left[{ }^{3} \mathrm{H}\right]$ thymidine incorporation (Fig. 7, lower panel). Again, Buserelin and GnRH caused dose-dependent reductions whereas Cetrorelix failed to do so. The effects on $\left[{ }^{3} \mathrm{H}\right]$ thymidine incorporation were clearly more pronounced than those on MTT activity (e.g. $10^{-8} \mathrm{M}$ Buserelin reduced MTT activity by $50 \%$ and $\left[{ }^{3} \mathrm{H}\right]$ thymidine incorporation by $80 \%$ ). In a final series of experiments, the influence of Antide and Cetrorelix on the inhibitory effect of Buserelin was assessed. As shown in Fig. 8, Buserelin caused the expected reduction in MTT activity $\left(\mathrm{EC}_{50}<10^{-11} \mathrm{M}\right)$. Antide and Cetrorelix had no measurable effect alone but clearly inhibited the Buserelin effect, shifting the Buserelin dose-response curve rightward and thereby increasing the $\mathrm{EC}_{50}$ to $>10^{-9} \mathrm{M}$.

\section{Discussion}

In addition to their expression in the pituitary, GnRH-Rs are also found in several hormone-dependent cancers (or cell lines derived from such cancers) where they can mediate effects on cell division or death, but their identity and mechanism of action remain controversial. Although identical type I GnRH-R transcripts have been found in pituitary and extra-pituitary sites, their operational characteristics may differ in different sites (Conn \& Crowley 1994, Stojilkovic et al. 1994, Imai et al. 1997, Sealfon et al. 1997, Grosse et al. 2000, Hislop et al. 2000, Gruendker 

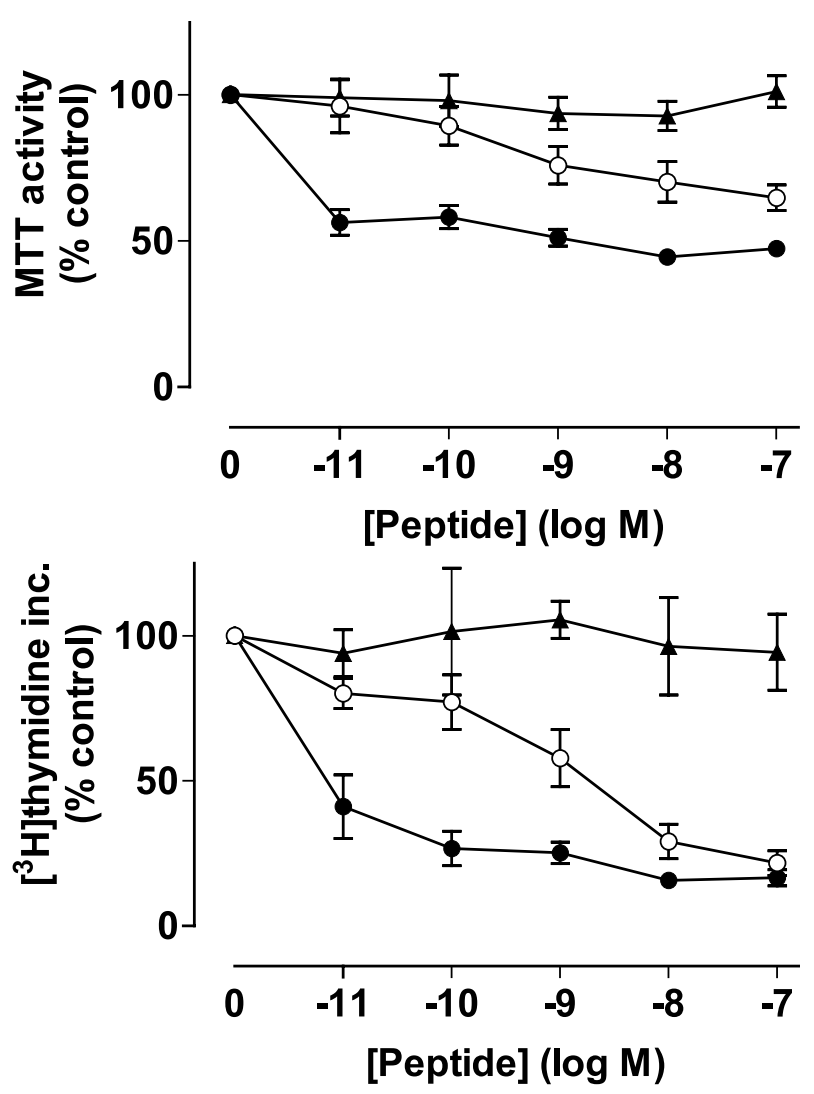

Figure $7 \mathrm{GnRH}-\mathrm{R}$-mediated effects on MTT activity and $\left[{ }^{3} \mathrm{H}\right]$ thymidine incorporation in PC3 cells: ligand specificity. Upper panel: the cells were cultured, Ad GnRH-R infected (100 p.f.u./cell) and stimulated as in Fig. 6 (sustained exposure to peptide) except that the indicated concentration of Buserelin (solid circles), GnRH (open circles) or Cetrorelix (triangles) were used. The figure presents data from five or more separate experiments (means \pm S.E.M.) each with four replicate observations. For pooling, the data were normalized as a percentage of the MTT activity in control cells receiving no peptide. The effects of Buserelin were statistically significant at all concentrations tested $(P<0 \cdot 05)$ and the effects of $\mathrm{GnRH}$ were statistically significant at $10^{-8}$ and $10^{-7} \mathrm{M}$ concentrations $(P<0 \cdot 05)$. Lower panel: the cells were treated as in the upper panel, except that $\left[{ }^{3} \mathrm{H}\right]$ thymidine incorporation (rather than MTT activity) was measured on the last day of culture. Statistically significant $(P<0 \cdot 05)$ inhibition was seen with all concentrations of Buserelin and with $10^{-9}-10^{-7} \mathrm{M} \mathrm{GnRH}$.

et al. 2001, Limonta et al. 2001). Perhaps the most puzzling observation is that antagonists can mimic the antiproliferative effect of GnRH-R agonists on some hormone-dependent cancer cell lines. In some models it appears that locally produced GnRH actually supports cell proliferation so that this paracrine or autocrine effect can be reduced by receptor blockade or by agonist-induced receptor down-regulation (Arencibia \& Schally 2000). In others, it is thought that GnRH-R activation inhibits proliferation (or causes cell death), in which case the identical effects of agonists and antagonists would imply

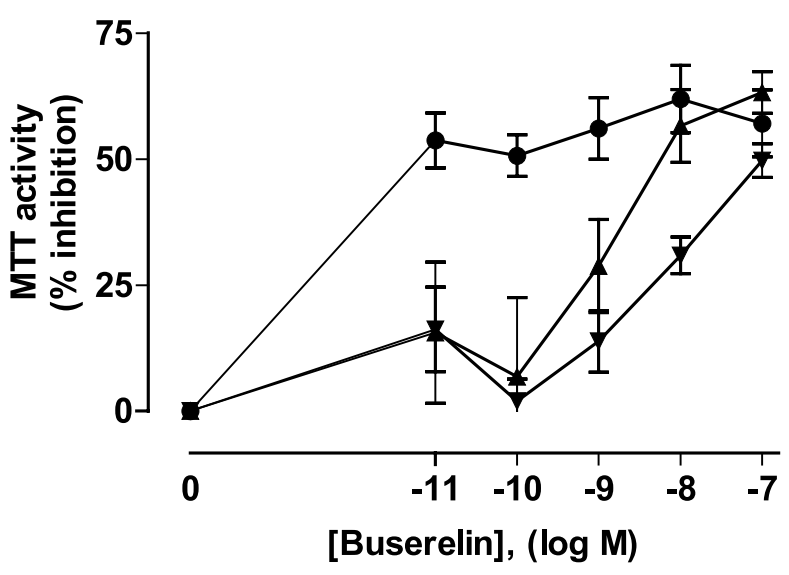

Figure 8 GnRH-R-mediated effects on MTT activity in PC3 cells: antagonist effects. The cells were cultured, Ad GnRH-R infected (100 p.f.u./cell) and stimulated as described in Fig. 6 (sustained exposure to peptide) except that the indicated concentrations of Buserelin were used either alone (solid circles) or with $10^{-7} \mathrm{M}$ Cetrorelix (upright triangles) or $10^{-7} \mathrm{M}$ Antide (inverted triangles). The data are from four separate experiments (means \pm S.E.M., $n=4$ ) each of which had four replicate observations. For pooling, the data were normalized as percentage inhibition of control MTT activity (that seen in control cells receiving no peptide).

that the agonist/antagonist dichotomy defined largely with pituitary GnRH-Rs does not hold for receptors of extra-pituitary sites (Emons et al. 1997, Limonta et al. 1997, 2001).

In order to explore the context-dependence of GnRH-R function, we have previously generated recombinant adenovirus expressing mammalian GnRH-Rs and have previously used these to express GnRH-Rs in human mammary cancer cells (Everest et al. 2001). Although we were unable to detect endogenous GnRH-Rs, adenoviral infection enabled us to express GnRH-Rs in these cells at a range of densities encompassing physiological levels for pituitary GnRH-Rs. Using this approach we found that although mammalian GnRH-Rs can mediate a direct inhibition of proliferation in human mammary cancer cells, they are functionally indistinguishable from their pituitary counterparts (Everest et al. 2001). The obvious limitation of this work is that we may have simply chosen the wrong model system to reveal the contextdependence of GnRH-R signalling. For this reason, we have extended these studies to other hormone-dependent cancer cell lines. Here we have explored the functional characteristics of $\mathrm{GnRH}-\mathrm{Rs}$ expressed in a human prostate cancer cell line (PC3 cells) by means of recombinant adenovirus. PC3 cells were used because a large proportion of human prostate cancers appear to express GnRH-Rs (Qayum et al. 1990, Schally 1999, Halmos et al. 2000, Schally et al. 2001) and because evidence exists that GnRH-Rs expressed by prostate cancer-derived cell lines can mediate direct inhibition of proliferation but differ 
functionally from those of the pituitary. Androgenindependent cells were used because of the suggestion that GnRH-R activation can cause transactivation of steroid receptors (Turgeon \& Waring 1994) and adenovirusmediated transfection was used because it is vastly more efficient than standard transfection techniques in these cells.

Intact cell binding assays revealed no endogenous binding sites in control cells, but specific $\left[{ }^{125} \mathrm{I}\right]$ Buserelin binding was clearly increased after infection with Ad GnRH-R. Curve fitting revealed high affinity sites $\left(K_{\mathrm{d}}\right.$ $1 \cdot 1 \mathrm{nM}$ for Buserelin), and increasing viral titre from 3 to 300 p.f.u./cell increased the number of binding sites through a range (approximately 2000 to 275000 sites/cell) that encompasses the physiological range for pituitary GnRH-Rs (20 000-70000 sites per gonadotroph) (Clayton \& Catt 1981, Loumaye \& Catt 1983, Everest et al. 2001). These sites had high affinity for Buserelin, GnRH, Cetrorelix and Antide, and lower affinity for cGnRH-II, and were functional, because GnRH failed to increase the cytoplasmic $\mathrm{Ca}^{2+}$ concentration or to stimulate $\left[{ }^{3} \mathrm{H}\right] \mathrm{IP}$ accumulation in control cells, but did so after infection with Ad GnRH-R. The rank order of potency for stimulation of $\left[{ }^{3} \mathrm{H}\right] \mathrm{IP}$ accumulation was identical to that seen in competition binding experiments (Buserelin $=\mathrm{GnRH}>\mathrm{cGnRH}-\mathrm{II})$. Similar results were obtained in Du-145 cells (an androgen-dependent human prostate cancer derived cell line) and in MCF7 breast cancer cells (Everest et al. 2001). In all three systems we were unable to detect endogenous GnRH-Rs but infection with Ad GnRH-R facilitated expression of high affinity phospholipase C-coupled receptors showing identical ligand specificity to that shown here.

Exploring possible GnRH-R-mediated effects on proliferation, no effect of sustained stimulation with Buserelin or GnRH on cell number (as revealed by MTT assays) was observed in either control cells receiving no adenovirus or in cells infected with a control 'empty' adenovirus. This is in apparent contradiction of earlier work showing direct inhibition of PC3 cell proliferation by $\mathrm{GnRH}$ analogues (Limonta et al. 1992, Palyi et al. 1999) but is in accord with the lack of endogenous receptor binding and signalling (data herein) and with previous work showing no inhibition of proliferation (Bahk et al. 1998). The reasons for such discrepancies are unknown but could relate to culture conditions, particularly since these have been shown to cause selection of functionally distinct sub-populations of PC3 cells (Festuccia et al. 2000). Clearly, however, the cells and protocols used herein reveal no evidence of endogenous GnRH-Rs and this model does not provide an opportunity to compare endogenous and exogenous GnRH-Rs. Instead, it enables functional characterization of the latter, in isolation. Doing so, we found that $\mathrm{GnRH}$ and Buserelin both caused a pronounced and potent reduction in cell number, after infection of PC3 cells with Ad GnRH-R (Fig. 5). This effect was dependent upon viral titre (e.g. receptor number) and required sustained stimulation, since no inhibition was seen after stimulation for only 1 or $4 \mathrm{~h}$ (Fig. 6). It was also ligand-specific because Buserelin was more potent than GnRH (minimum effective concentrations of $10^{-11}$ and $10^{-9} \mathrm{M}$ respectively) and Cetrorelix had no measurable effect, even at $10^{-7} \mathrm{M}$ (Fig. 7). Qualitatively similar data were obtained by measurement of $\left[{ }^{3} \mathrm{H}\right]$ thymidine incorporation on the last day of culture (Fig. 7) except that the effect was more pronounced (e.g. 80\% maximal inhibition of $\left[{ }^{3} \mathrm{H}\right]$ thymidine incorporation as compared with $50 \%$ maximal reduction in MTT activity). The greater reduction of $\left[{ }^{3} \mathrm{H}\right]$ thymidine incorporation indicates that it is not simply a consequence of the reduced cell number. Indeed, it is more likely that agonists have inhibited cell proliferation (thereby reducing cell number) and that the greater reduction in $\left[{ }^{3} \mathrm{H}\right]$ thymidine incorporation occurs because this assay compounds the reduction in cell number and proliferation rate. Similar data were obtained in the androgen-dependent Du-145 prostate cancer cell line (not shown) and in MCF7 cells (Everest et al. 2001).

An intriguing distinction was observed between the concentration-response relationships seen with different assays. Thus, Buserelin was 100-1000 times more potent than GnRH at inhibition of proliferation (Fig. 7) but was barely distinguishable from $\mathrm{GnRH}$ in binding assays or at stimulation of $\left[{ }^{3} \mathrm{H}\right] \mathrm{IP}$ accumulation (Figs 2 and 3). In vivo, the high potency of Buserelin (as compared with $\mathrm{GnRH}$ ) is attributed to its resistance to degradation and the same may hold true in the proliferation assays, since sustained stimulation with agonist is needed for this effect (Fig. 6).

In summary, we have shown that recombinant adenovirus provides an efficient means of expressing functional GnRH-Rs in human prostate cancer cells and that varying viral titre enables the control of receptor number over a range encompassing physiological levels of pituitary GnRH-Rs. We have found no evidence for contextdependent GnRH-R signalling but have shown, instead, that human prostate cancer cells certainly are capable of expressing high affinity GnRH-Rs which are functionally indistinguishable from endogenous gonadotroph GnRH-Rs or from GnRH-Rs transfected into gonadotroph lineage cells. We were unable to detect endogenous GnRH-Rs or effects of GnRH on proliferation in control cells, and infection with Ad GnRH-R did not increase proliferation rates (as might be expected if endogenous GnRH were exerting a trophic effect). Instead, infection with Ad GnRH-R facilitated a receptor-mediated inhibition of proliferation, as evidenced by a reduction in cell number and rate of $\left[{ }^{3} \mathrm{H}\right]$ thymidine incorporation per cell. This effect was inhibited (rather than mimicked) by GnRH-R antagonists and was increased as adenoviral titre (i.e. receptor number) was increased. Thus, GnRH-R activation is inhibitory for proliferation of these cells and strategies designed to increase or maintain GnRH-Rs may 
therefore be useful in maximizing direct antiproliferative effects mediated by extra-pituitary GnRH-Rs.

\section{Acknowledgement}

This work was supported by the Wellcome Trust $(059795$ to $\mathrm{C}$ A M).

\section{References}

Arencibia JM \& Schally AV 2000 Luteinizing hormone releasing hormone as an autocrine growth factor in ES-2 ovarian cancer cell line. International Journal of Oncology 16 1009-1013.

Bahk JY, Hyun JS, Lee H, Kim MO, Cho GJ, Lee BH \& Choi WS 1998 Expression of gonadotropin-releasing hormone $(\mathrm{GnRH})$ and GnRH receptor mRNA in prostate cancer cells and effect of $\mathrm{GnRH}$ on the proliferation of prostate cancer cells. Urology Research 26 259-264.

Barbieri RL 1992 Clinical applications of GnRH and its analogues. Trends in Endocrinology and Metabolism 3 30-34.

Clayton RN \& Catt KJ 1981 Gonadotropin-releasing hormone receptors: characterization, physiological regulation, and relationship to reproductive function. Endocrine Reviews 2 186-209.

Conn PM \& Crowley WFJ 1994 Gonadotropin-releasing hormone and its analogs. Annual Review of Medicine 45 391-405.

Dondi D, Limonta P, Moretti RM, Marelli MM, Garattini E \& Motta M 1994 Antiproliferative effects of luteinising hormone releasing hormone (LHRH) agonists on human androgen-independent prostate cancer cell line DU-145: evidence for an autocrine inhibitory LHRH loop. Cancer Research 54 4091-4095.

Emons G \& Schally AV 1994 The use of luteinizing hormone releasing hormone agonists and antagonists in gynaecological cancers. Human Reproduction 9 1364-1379.

Emons G, Muller V \& Ortmann O 1996 Luteinizing hormone releasing hormone agonist triptorelin antagonizes signal transduction and mitogenic activity of epidermal growth factor in human ovarian and endometrial cancer cell lines. International Journal of Oncology 9 $1129-1137$.

Emons G, Ortmann O, Schulz KD, Schally AV \& Emons G 1997 Growth inhibitory actions of analogues of luteinizing hormone releasing hormone on tumour cells. Trends in Endocrinology and Metabolism 8 355-362.

Emons G, Muller V, Ortmann O \& Schulz KD 1998 Effects of LHRH-analogues on mitogenic signal transduction in cancer cells. Journal of Steroid Biochemistry and Molecular Biology 65 199-206.

Everest HM, Hislop JN, Harding T, Uney JB, Flynn A, Millar RP \& McArdle CA 2001 Signaling and antiproliferative effects mediated by $\mathrm{GnRH}$ receptors after expression in breast cancer cells using recombinant adenovirus. Endocrinology 142 4663-4672.

Festuccia C, Gravina GL, Anguelucci A, Millimagi D \& Bologna M 2000 Culture conditions modulate phenotype and cause selection of subpopulations in PC3 prostate cancer cell line. Anticancer Research 20 4367-4371.

Grosse R, Schmid A, Schoneberg T, Herrlich A, Muhn P, Schultz G \& Gudermann T 2000 Gonadotropin-releasing hormone receptor initiates multiple signaling pathways by exclusively coupling to G(q/11) proteins. Journal of Biolical Chemistry 275 9193-9200.

Gruendker C \& Emons G 2001 Biology of GnRH systems in cancer and human reproduction. In GnRH Analogues. The State of the Art 2001, pp 15-42. Ed. B Lunenfeld. New York, USA: Parthenon Publishing Group.

Gruendker C, Volker P \& Emons G 2001 Anti-proliferative signalling of luteinizing hormone-releasing hormone in human endometrial and ovarian cancer cells through G-protein alpha(I)-mediated activation of phosphotyrosine phosphatase. Endocrinology 142 2369-2380.

Halmos G, Arencibia JM, Schally AV, Davis R \& Bostwick DG 2000 High incidence of receptors for luteinising hormone releasing hormone $(\mathrm{LHRH})$ and $\mathrm{LHRH}$ receptor gene expression in human prostate cancers. Journal of Urology 163 623-629.

Hislop JN, Madziva MT, Everest H, Harding TC, Uney JB, Willars G, Millar R, Troskie B, Davidson J \& McArdle CA 2000 Desensitization and internalization of human and Xenopus gonadotropin-releasing hormone receptors expressed in $\alpha \mathrm{T} 4$ pituitary cells using recombinant adenovirus. Endocrinology 141 4564-4575.

Imai A, Horibe S, Takagi A \& Tamaya T 1997 G $_{i}$ protein activation of gonadotropin-releasing hormone-mediated protein dephosphorylation in human endometrial carcinoma. American Journal of Obstetrics and Gynecology 176 371-376.

Jungwirth A, Galvan G, Pinski J, Halmos G, Szepeshazi K, Cai RZ, Groot K \& Schally AV 1997 Luteinizing hormone-releasing hormone antagonist Cetrorelix (SB-75) and bombesin antagonist RC-3940-II inhibit the growth of androgen-independent PC-3 prostate cancer in nude mice. Prostate 32 164-172.

Kakar SS, Grizzle WE \& Neill JD 1994 The nucleotide sequences of human GnRH-R in breast and ovarian tumors are identical with that found in pituitary. Molecular and Cellular Endocrinology 106 145-149.

Limonta P, Dondi D \& Moretti RM, Maggi R \& Motta M 1992 Antiproliferative effects of luteinising hormone-releasing hormone agonists on the human prostatic cancer cell line LNCaP. Journal of Clinical Endocrinology and Metabolism 75 207-212.

Limonta P, Pratesi G, Moretti RM, Montagnani-Marelli M, Motta M \& Dondi D 1998 Comments on inhibition of growth of androgen-independent DU-145 prostate cancer in vivo by luteinising hormone-releasing hormone antagonist Cetrorelix and Bombesin antagonist RC-3940-II and RC-3950-II, Jungwirth et al. European Journal of Cancer 199733 1141-1148. European Journal of Cancer 34 1134-1136.

Limonta P, Montagnani-Marelli M \& Moretti RM 2001 LHRH analogues as anticancer agents: pituitary and extrapituitary action. Expert Opinions Investigating Drugs 10 709-720.

Loumaye E \& Catt KJ 1983 Agonist-induced regulation of pituitary receptors for gonadotropin-releasing hormone: dissociation of receptor recruitment from hormone release in cultured gonadotrophs. Journal of Biological Chemistry 258 12002-12009.

McArdle CA, Schomerus E, Groner I \& Poch A 1992a Estradiol regulates gonadotropin-releasing hormone receptor number, growth and inositol phosphate production in $\alpha \mathrm{T} 3-1$ cells. Molecular and Cellular Endocrinology 87 95-103.

McArdle CA, Bunting R \& Mason WT $1992 b$ Dynamic video imaging of cytosolic $\mathrm{Ca}^{2+}$ in the $\alpha \mathrm{T} 3-1$, gonadotrope-derived cell line. Molecular and Cellular Neuroscience 3 124-132.

Miller WR, Scott WN, Morris R, Fraser HM \& Sharpe RM 1985 Growth of human breast cancer cells inhibited by a luteinizing hormone-releasing hormone agonist. Nature 313 231-233.

Moretti RM, Marelli MM, Dondi D, Poletti A, Martini L, Motta M \& Limonta P 1996 Luteinizing hormone-releasing hormone agonists interfere with the stimulatory actions of epidermal growth factor in human prostatic cancer cell lines, LNCaP and DU 145. Journal of Clinical Endocrinology and Metabolism 81 3930-3937.

Motta M, Dondi D, Moretti M, Montagnani-Marelli M, Pimpinelli F, Maggi R \& Limonta R 1996 Role of growth factors, steroid and peptide hormones in the regulation of human prostatic tumor growth. Journal of Steroid Biochemistry and Molecular Biology $\mathbf{5 6}$ 107-111.

Palyi I, Vincze B, Lovas S, Mezo I, Pato J, Kalnay A, Turi G, Gaal D, Mihalik R, Peter I, Teplan I \& Murphy RF 1999 Gonadotropin-releasing hormone analogue conjugates with strong selective antitumour activity. PNAS 96 2361-2366. 
Qayum A, Gullick W, Clayton RC, Sikora K \& Waxman J 1990 The effects of gonadotropin-releasing hormone analogues in prostate cancer are mediated through specific tumor receptors. British Journal of Cancer 62 96-99.

Ravenna L, Salvatori L, Morrone S, Lubrano C, Cardillo MR, Sciarra F, Frati L, Di Silverio F \& Petrangeli E 2000 Effects of triptorelin, a gonadotropin-releasing hormone agonist, on the human prostatic cell lines PC3 and LNCaP. Journal of Andrology 21 549-557.

Schally AV 1999 LH-RH analogues: their impact on human reproduction and the control of tumorigenesis. Peptides $\mathbf{2 0}$ $1247-1262$

Schally AV, Halmos G, Rekasi Z \& Arencibia-Jiminez JM 2001 The actions of luteinising hormone-releasing hormone agonists, antagonists, and cytotoxic analogues on the LHRH receptors on the pituitary and tumors. Infertility and Reproductive Medicine Clinics of North America 12 1-28.

Sealfon SC, Weinstein H \& Millar RP 1997 Molecular mechanisms of ligand interaction with the gonadotropin-releasing hormone receptor. Endocrine Reviews 18 180-205.
Stojilkovic SS \& Catt KJ 1995 Expression and signal transduction pathways of gonadotropin-releasing hormone receptors. Recent Progress in Hormone Research 50 161-205.

Stojilkovic SS, Reinhart J \& Catt KJ 1994 Gonadotropin-releasing hormone receptors: structure and signal transduction pathways. Endocrine Reviews 462-497.

Turgeon JL \& Waring DW 1994 Activation of the progesterone receptor by the gonadotropin-releasing hormone self-priming signaling pathway. Molecular Endocrinology 7 860-869.

Williams B, Forrest-Owen W, Stephenson R, Fowkes RC \& McArdle CA 2000 Oestradiol is an essential mitogen and modulator of GnRH signaling in $\alpha \mathrm{T} 3-1$ cells: are these effects causally related? Journal of Endocrinology 164 31-43.

Received 9 October 2002

Accepted 25 October 2002 